\title{
CA-IESO 法を用いた構造体の位相最適化 TOPOLOGY OPTIMIZATION OF STRUCTURES USING CA-IESO METHOD
}

\author{
藤 井大 地 ${ }^{* 1}$, 山下 真 輝 ${ }^{* 2}$, 清水 満喜子*3 \\ Daiji FUJII, Masaki YAMASHITA and Makiko SHIMIZU
}

\begin{abstract}
In this paper, we propose a topology optimization method using CA (Cellular Automaton) method and IESO (Improved Evolutionary Structural Optimization) method. In this method, unlike conventional method, the initial morphology is arbitrary. If the number of elements in the initial morphology is less than target number of elements, elements are added by CA method, otherwise, the elements are removed by IESO method. By using this method, it is possible to evolve from the initial morphology created by designer to the optimal morphology. In this paper, the effectiveness of the proposed method is verified by basic examples and an applied example.
\end{abstract}

Keywords : Topology optimization, ESO method, CA method, Voxel FEM, Computational morphogenesis 位相最適化，ESO 法，CA 法，ボクセル有限要素法，形態創生

\section{1. はじめに}

ボクセル有限要素法を用いた位相最適化手法は，ボクセル分割さ れた 3 次元の直方体固定設計領域から力学的合理性を有する多様な 構造形態を創生できる手法である. 藤井ら 1,2) は, このような手法を 用いて建築構造の形態創生を試みている. また, 藤井, 山下ら ${ }^{3) は, ~}$ 有限要素法の代わりに粒子法（HMPS 法）を用いることで，このよ うな手法を，有限変形を考慮できる手法に発展させている．

ところで，このようなボクセル解析法を用いた位相最適化では， 固定設計領域のボクセルの材料密度が均等な状態から出発して解形 態を求める方法が一般的である。これは, 数理計画法にもとづく SIMP（Solid Isotropic Material with Penalization）法 4)やレベル セット法 5), 発見的手法である BESO (Bi-directional Evolutionary Structural Optimization）法 6,7)でも同様である.しかしながら, 同 じBESO でも, Querin ら ${ }^{8}$ は, 固定設計領域に要素数の少ない単 純な初期形態を設定し, そこから進化させて最適解を得る方法を提 案している。また，三井9)も，CA（Cellular Automaton）法で，同 様の初期形態から進化させて最適解を得る方法を提案している. た だし, これら 2 つの方法は, 進化の感度指標として相当応力（Von Mises stress）を用いている. その後, BESO 法 6,7は, 進化の感度 指標として, 剛性最大化問題の目的関数であるコンプライアンス(外 力仕事量）の感度（要素ひずみエネルギーの 2 倍）を用いる方法に 発展しているが, 要素数の少ない単純な初期形態から進化させる方 法は用いられていない。これは, 要素数の少ない単純な初期形態か ら出発すると, 局所最適解に陥る可能性が高いためと考えられる.

ところで， 3 次元解析では, 固定設計領域の要素（ボクセル）数 は数十万から数百万になり, 目標とする解の要素数はその $10 \%$ 程度
となる場合が多いため，要素数の少ない初期形態から出発して最適 解が求まれば, 特に粒子法を用いる解析では, 計算効率を大幅に改 善できる．また, 最適化問題では, 設計者が設定した初期形態を尊 重しながら修正を加える問題もあるため, 最適化手法としては, ど のような初期形態から出発しても最適解が得られることが望ましい，

このような多様な初期形態から進化させることが可能な位相最適 化手法としては，文献 8,9)の手法の他に藤井ら 10,11)が提案した CAESO 法がある。しかしながら，本手法では進化の感度指標として文 献 8,9) と同様にVon Mises 応力を用いている．また，要素除去に用 いている闇值パラメータを手動で設定しているため, 最適なパラメ ータを求めるために解析例ごとの試行錯誤が必要であった．このよ うな問題を解決したのが, 文献 1,2)で提案している IESO (Improved ESO)である.しかしながら,これまで提案した CA-ESO 法も IESO 法も，すべての設計対象要素（材料密度が変化する要素）の初期密 度を 1 とする形態から出発して最適解を求めており, 要素数の少な い（設計対象要素の初期密度に多くの 0 を含む）単純な初期形態か ら最適解を求めることは想定していなかった.

そこで本論文では，多様な初期形態から最適解を求める方法とし て, CA 法と IESO 法を組み合わせた CA-IESO 法を改めて提案し, その有効性を検証する. 検証方法としては, まず，文献 8,9)に示さ れている基本的な例題に対して, 全設計対象要素の初期密度を 1 と した形態から出発した最適解と, 要素数の少ない（設計対象要素の 初期密度に 0 を含む) 形態から出発した最適解を比較し, 要素数の 少ない単純な初期形態から進化させても有効な解が得られることを 確かめる。また，文献 10,11)で提案している CA-ESO 法について も, 提案手法との比較を行い, 両手法の違いを明確にする.
近畿大学工学部 教授·博士 (工学) 北條建築構造研究所 修士 (工学)

近畿大学大学院 システム工学研究科大学院生
Prof., Faculty of Engineering, Kindai University, Dr.Eng.

Hojo Structure Research Institute, M.Eng.

Grad. Student, Graduate School of Systems Engineering, Kindai University 
次に, 建築構造への応用例として, 鉛直荷重と地震力が加わる床 スラブを一部の支持領域から支える構造体の形態創生を行い，全設 計対象要素の初期密度を 1 とした形態から求めた最適解と, 支持領 域と床スラブを繋ぐ 1 本の柱部分の要素の初期密度のみを 1 とし, 他を 0 とした形態から求めた最適解を比較することにより, 提案手 法の有効性を検証する.

なお, 本論文で提案する CA-IESO 法も, すでに提案している CAESO 法, IESO 法（十仕上アルゴリズム）も, 発見的手法であるた め, 得られた解が剛性最大化問題の最適解であるという保証はない. しかし, これまでの研究 1,2,10,11)で, CA-ESO 法, IESO 法 (+仕上 アルゴリズム) の解は, SIMP 法と同条件で同等以上の剛性を有す る解が得られることが検証されているため, 本論文では, 提案手法 (CA-IESO 法) の全設計対象要素の初期密度を 1 とする初期形態 から求めた最適解 (収束解) を大域的最適解近傍の解と考えて比較 検証を行う.また, ボクセル解析法としては, 有限要素法 1,2) と粒子 法（HMPS 法）3)があるが, 本論文では, 弾性微小変形問題を対象 とし，有限要素法を用いるものとする.

\section{CA-IESO 法による位相最適化}

本論文に用いる位相最適化手法では, 辺の長さ $L_{X}, L_{Y}, L_{Z}$ の直方 体固定設計領域を考え, これを均等な直方体要素（ボクセル）で分 割する (各辺の要素分割数: $n_{X}, n_{Y}, n_{Z}$ ). そして, 構造体の物理領 域は要素の材料密度（以下, 要素密度と呼ぶ）の有無（1/0）によっ て与える. この場合, 要素各辺の長さ $l_{X}, l_{Y}, l_{Z}$ は, $I_{X}=L_{X} / n_{X}$, $l_{Y}=L_{Y} / n_{Y}, l_{Z}=L_{Z} / n_{Z}$ で与えられる. また, 有限要素は 8 節点応 力仮定法要素 (要素内の変位と応力がともに線形で仮定される要素) とし, 全体剛性方程式の解法には前処理付き共役勾配法を用いる 1).

\section{1 従来の手法 (CA-ESO 法と IESO 法（＋仕上アルゴリズム))}

提案手法である CA-IESO 法は, CA-ESO 法 10,11) と IESO 法（+ 仕上アルゴリズム） 1,2)を改良したものであるが，ここでは，従来の 手法と新しく提案する手法の違いを明確にするため, 従来の CAESO 法と IESO 法について少し詳しい説明を加える.

まず，CA-ESO 法と IESO 法は，いずれも発見的手法であるが， 一応，次式の最適化問題の解を求めることを想定している.

$$
\begin{aligned}
& \text { Minimize }: C(\boldsymbol{\rho})=\mathbf{d}^{T} \mathbf{f}=\mathbf{d}^{T} \mathbf{k d} \\
& \text { subject to }: V_{r}(\boldsymbol{\rho})=\sum_{i=1}^{N} \rho_{i} / N \leq \bar{V}_{r} \\
& \text { where, } \\
& \boldsymbol{\rho}=\left\{\rho_{1}, \rho_{2} \cdots, \rho_{i}, \cdots, \rho_{N}\right\}, \quad 0 \leq \rho_{i} \leq 1, \quad N=n_{X} \cdot n_{Y} \cdot n_{Z} \\
& \mathbf{k}_{i}=\rho_{i} \mathbf{k}_{i}^{\text {ini }}, \quad \alpha_{i}^{e}=\frac{\partial C(\boldsymbol{\rho})}{\partial \rho_{i}}=-\mathbf{d}_{i}{ }^{T} \frac{\partial \mathbf{k}_{i}}{\partial \rho_{i}} \mathbf{d}_{i}=-\mathbf{d}_{i}{ }^{T} \mathbf{k}_{i}^{\text {ini }} \mathbf{d}_{i}
\end{aligned}
$$

ここに, $C$ はコンプライアンス (外力仕事量) $, \mathrm{d}, \mathrm{f}, \mathrm{k}$ は, 節点変 位ベクトル, 外力ベクトル, 全体剛性マトリクス, $V_{r}$ は総密度比, $\bar{V}_{r}$ は総密度比の制約值, $N$ は設計領域の全要素数を表す．また， $\rho$ は設計変数, $\rho_{i}$ は $i$ 番目要素の要素密度, $\mathbf{k}_{i}, \mathbf{k}_{i}^{\mathrm{ini}}, \mathbf{d}_{i}$ は $i$ 番目要素 の要素剛性マトリクス, 初期要素剛性マトリクス, 要素の節点変位 ベクトルを表す. また, $\alpha_{i}^{e}$ は $i$ 番目要素密度に対する目的関数の感 度（微分）を表し, この場合は, 要素のひずみエネルギーの 2 倍 $\left(\mathbf{d}_{i}{ }^{T} \mathbf{k}_{i}^{\mathrm{ini}} \mathbf{d}_{i}\right)$ となる ${ }^{1)}$. なお, 以下では, $\mathbf{d}_{i}{ }^{T} \mathbf{k}_{i}^{\text {ini }} \mathbf{d}_{i}$ で表される感度 を要素ひずみエネルギーと呼ぶ（2 倍を省略）。
ただし，(1)式に示される感度（要素ひずみエネルギー）は，最近 の位相最適化手法 1,2,6,7)では，Fig.1 に示すように次式により節点感 度 $\alpha_{j}^{n}$ に変換され,

$$
\alpha_{j}^{n}=\left(\sum_{i=1}^{M_{j}^{e}} \alpha_{i}^{e}\right) / M_{j}^{e}
$$

さらに次式により, 要素中心から影響半径 $r_{\text {min }}\left(=b_{r} \cdot l_{X}\right)$ 内の節点感 度の重み付き平均として平滑化される.

$$
\alpha_{i}=\left(\sum_{j=1}^{M_{i}^{n}} W\left(r_{i j}\right) \alpha_{j}^{n}\right) / \sum_{j=1}^{M_{i}^{n}} W\left(r_{i j}\right), \quad W\left(r_{i j}\right)=r_{\min }-r_{i j}
$$

ここで, (2)式の $M_{j}^{e}$ は $j$ 番目節点に繋がる要素数，(3)式の $M_{i}^{n}$ は $i$ 番目要素の要素中心から影響半径 $r_{\text {min }}$ の球体内に含まれる節点数, $r_{i j}$ は $i$ 番目要素の中心から $j$ 番目節点までの距離を表す. また, $I_{X}$ はボクセルの $X$ 方向長さ， $b_{r}$ はその倍率（影響半径倍率）を表す. なお，このような感度の平滑化はフィルタリング（Filtering）法と 呼ばれ,よりシンプルな構造形態を求めるために有効な手法である.
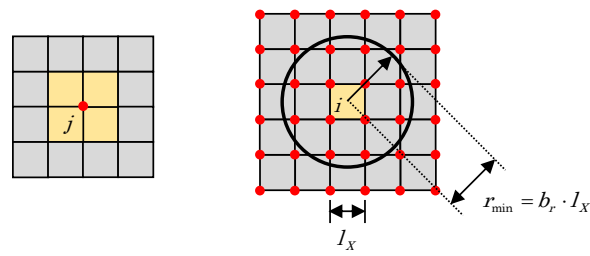

Fig.1 Filtering method

(1)式の最適化問題は, 一般には, 数理計画法によって解かれるが, その場合, 要素密度 $\rho_{i}$ を 0 から 1 の連続変数にする必要がある.こ れに対して, 発見的手法では, 要素密度 $\rho_{i}$ を 0 または 1 の離散変数 として解くことができ, BESO 法等の進化的手法では, 構造解析（最 適化ステップ）を繰り返すことで，各要素の感度指標にもとづき， 感度指標の低い要素を除去（要素密度 $1 \rightarrow 0 ） し$, 感度指標の高い要 素を付加（要素密度 $0 \rightarrow 1 ）$ することで最適解（優良解）を求める.

CA-ESO 法と IESO 法は，いずれも進化的手法であるが，要素の 除去と付加のアルゴリズムに特徴があり, 要素除去に関しては, 次 式の閾值 ${ }^{12)}$ を用いた除去を行う。

$$
\rho_{i}=0 \quad \text { if } \quad \alpha_{i}^{(k)}<X_{c r}{ }^{(k)} \quad ; i=1, \cdots, N_{L}{ }^{(k)}
$$

$$
X_{c r}{ }^{(k)}=\alpha_{a v}{ }^{(k)}-\eta_{E}{ }^{(k)} \cdot \phi^{(k)}
$$

$$
\alpha_{a v}{ }^{(k)}=\frac{1}{N_{L}{ }^{(k)}} \sum_{i=1}^{N_{L}} \alpha_{i}^{(k)}, \quad \phi^{(k)}=\sqrt{\frac{1}{N_{L}{ }^{(k)}} \sum_{i=1}^{N_{L}}\left(\alpha_{i}{ }^{(k)}-\alpha_{a v}{ }^{(k)}\right)^{2}}
$$

ここで, $\alpha_{i}^{(k)}$ は, 最適化の第 $k$ ステップにおける $i$ 番目要素の感度 指標, $X_{c r}{ }^{(k)}$ は閾値, $N_{L}{ }^{(k)}$ は残存要素数, $\alpha_{a v}{ }^{(k)}, \phi^{(k)}$ は残存要素の 感度指標の平均值と標準偏差, $\eta_{E}{ }^{(k)}$ は除去要素数を制御するパラメ 一タを表す，一方，要素の付加に関しては，次式の CA 法 9)にもと づく付加を行う.

$$
\rho_{s_{i j}}=1 \quad \text { if } \quad \alpha_{i}^{(l)} \geq \eta_{A}{ }^{(l)} \cdot \alpha_{a v}{ }^{(l)} \quad ; i=1, \cdots, N_{L}{ }^{(l)}
$$

ここで, $S_{i j}\left(j=1, \cdots, n_{i}\right)$ は $i$ 番目要素と面を共有する要素（ノイマ ン近傍要素）の要素番号を表し， $n_{i}$ はその要素数（内部では 6 , 境 
界では 6 未満）を表す.また， $\alpha_{i}{ }^{(I)}, \alpha_{a v}{ }^{(I)}$ は最適化の第 1 ステップ における $i$ 番目要素の感度指標之残存要素の感度指標の平均値, $\eta_{A}{ }^{(I)}$ は付加要素数を制御するパラメータを表す. なお, CA-ESO 法 と IESO 法では, 同じ最適化のステップで, 除去と付加を同時に行 うことはないため, ここでは, 除去ステップと付加ステップを $k$ と Iで分けている.

ただし, CA-ESO 法では, 感度指標として(1)式の要素ひずみエネ ルギー $\left(\mathbf{d}_{i}{ }^{T} \mathbf{k}_{i}^{\text {ini }} \mathbf{d}_{i}\right)$ ではなく, Von Mises 応力を用いており, IESO 法では, これを要素ひずみエネルギーを用いる方法に改善している. また, IESO 法では, この改善に伴い, (5)式のパラメータ $\eta_{E}{ }^{\left({ }^{k}\right)}$ の設 定法に改良を加えている. 寸なわち, CA-ESO 法では, $\eta_{E}{ }^{\left({ }^{k}\right)}$ の基準 值 $\eta_{E}$ を入力データとして与えるのに対し, IESO 法では, $\eta_{E}$ の代わ りに要素除去率 $\lambda_{E}$ を入力データとして与え, この $\lambda_{E}$ から第 $k$ ステ ップの目標除去要素数 $N_{R}{ }^{(k)}$ 党次式から算出する.

$$
N_{R}^{(k)}=\left\{\begin{array}{lll}
\lambda_{E} N_{L}^{(k-1)} & \text { if } & \left(1-\lambda_{E}\right) N_{L}^{(k-1)} \geq \bar{V}_{r} \cdot N \\
N_{L}^{(k-1)}-\bar{V}_{r} \cdot N & \text { if } & \left(1-\lambda_{E}\right) N_{L}^{(k-1)}<\bar{V}_{r} \cdot N
\end{array}\right.
$$

ただし， $\bar{V}_{r} \cdot N$ は残存要素数の制約值 (以下では, $\bar{V}_{r}$ を目標要素数 比と呼ぶ）を表す，そして，(8)式の目標除去要素数 $N_{R}^{\left({ }^{(k)}\right.}$ に近くな るように, プログラム内で, (4)式の $\eta_{E}{ }^{\left({ }^{k}\right)}$ を 0.001 刻み（制約条件 近傍 ((8)式の 2 行目の条件) では 0.0001 刻み) で自動探查する ${ }^{1,2}$. したがって, IESO 法の $\eta_{E}{ }^{\left({ }^{k}\right)}$ はステップごとに変化する.

これに対して, CA-ESO 法では, 残存要素 $N_{L}{ }^{(k)}$ が次式の条件を 満たす場合は $\eta_{E}{ }^{\left({ }^{k}\right)}=\eta_{E}$ が保持され,

$$
\begin{aligned}
& 0.1 \leq\left(N_{L}^{(k-1)}-N_{L}^{(k)}\right) / N_{L}^{(k-1)} \leq 0.3 \text { if } N_{L}^{(k-1)}>1.2 \bar{V}_{r} \cdot N \\
& 0 \leq\left(N_{L}^{(k-1)}-N_{L}^{(k)}\right) / N_{L}^{(k-1)} \leq 0.1 \text { if } N_{L}^{(k-1)}<1.2 \bar{V}_{r} \cdot N
\end{aligned}
$$

$N_{L}{ }^{(k)}$ が上式の条件を満たさない場合は, 上式の条件を満たす $\eta_{E}{ }^{(k)}$ が， $\eta_{E}$ を中心に 0.01 刻みで自動探査される.さらに, ESO 法によ る要素除去で, 残存要素が $\bar{V}_{r} \cdot N$ に達した後は, (9)式の 1 行目の式 の上下限值は, $0.1 \rightarrow 0.05,0.3 \rightarrow 0.2$ に, 2 行目の式の上限值は, 0.1 $\rightarrow 0.03$ に変更される.

一方, CA-ESO 法 10,11) と IESO 法の仕上アルゴリズム 2)における $\mathrm{CA}$ 法の要素付加パラメータ $\eta_{A}{ }^{(l)}$ は, 次式の条件を満たす場合は $\eta_{A}{ }^{(l)}=1.0$ とし,

$$
N_{L}^{(l)} \geq \bar{V}_{r} \cdot N
$$

残存要素 $N_{L}^{(l)}$ が上式の条件を満たさない場合は, 上式の条件を満 たす $\eta_{A}{ }^{(I)}$ が 1.0 を中心に 0.01 刻みで自動探査される.

\section{2 提案手法 (CA-IESO 法)}

以上の CA-ESO 法および IESO 法（十仕上アルゴリズム）は，設 計対象となる要素密度 $\rho_{i}$ の初期值がすべて 1 となる初期形態から 最適解を求める方法で, 設計対象要素の初期密度に 0 が含まれる形 態から最適解を求めることを想定していなかった，そこで本論文で は, 以上の手法を改良して, どのような初期形態からも最適解を探 査できる手法（CA-IESO 法）に発展させる.

提案手法である CA-IESO 法では, 最適化の第 $n$ ステップで, 残 存要素数 $N_{L}^{(n)}$ が目標要素数 $\left(\bar{V}_{r} \cdot N\right)$ 以上であれば IESO 法によ る要素除去 (要素密度 $1 \rightarrow 0$ ) を行い, 目標要素数以下であれば $\mathrm{CA}$ 法による要素付加（要素密度 $0 \rightarrow 1 ） を$ 行う. ただし, 要素除去のア
ルゴリズムは, IESO 法と同じとする，一方，要素付加のアルゴリ ズムは, IESO 法の要素除去の場合と同様に, 要素付加率 $\lambda_{A}$ を入力 データとして与え, 第 1 ステップの目標付加要素数を $\lambda_{A} N_{L}^{(l-1)}$ で計 算し，(7)式により付加される要素数が以下の条件を満足する $\eta_{A}{ }^{(l)}$ を，1.0を中心に 0.01 刻みで自動探査する.

$$
\lambda_{A} N_{L}^{(l-1)} \leq\left(N_{L}^{(l)}-N_{L}^{(I-1)}\right) \leq 1.5 \lambda_{A} N_{L}^{(l-1)}
$$

また, 最適化のステップが進み, コンプライアンスがある程度収 束した時点で文献 2) と同様の仕上アルゴリズムを適用する．ただし， 文献 2)の仕上アルゴリズムは, IESO 法で得られた収束解に微修正 を加えるものであり, 仕上過程の除去率は 0.01 , 付加要素数の上限 は $0.05 N$, 影響半径倍率は 1 に固定されていた。これに対して, $\mathrm{CA}-$ IESO 法では, 入力データとして, 初期の除去率 $\lambda_{E}$, 付加率 $\lambda_{A}$, 影響半径倍率 $b_{r}$ と, 仕上過程の除去率 $\lambda_{E}^{f}$, 付加率 $\lambda_{A}^{f}$, 影響半径倍 率 $b_{r}^{f}$ を別々に与え, また, 最適化の総ステップ数 $N_{T}$ と仕上開始ス テップ $N_{F}$ を与えることで， $\lambda_{E}, \lambda_{A}, b_{r}$ を用いる初期の最適化過 程から $\lambda_{E}^{f}, \lambda_{A}^{f}, b_{r}^{f}$ を用いる仕上過程まで一貫して解析が行えるよ うにする. また, $N_{F}$ を 0 にすると, 構造体の残存要素数が目標要 素数 $\bar{V}_{r} \cdot N$ に達した時点で自動的に仕上過程に移行するように設 定し, 従来の IESO 法（+仕上アルゴリズム）と同様の解析も行え るようにする．以上のような改良を加えることで，多様な初期形態 から最適化を行うことが可能となる.

なお, 本論文では, 構造解析に関する入力データは, VOXELCON ${ }^{13)}$ を利用して作成している. 寸なわち, VOXELCONにより, 直方体固 定設計領域のボクセル分割を行い, 各要素にヤング係数, ポアソン 比等の材料情報を割り当て, 境界条件, 荷重条件等を設定する。ま た, 本論文の解析では, 各要素の比熱と初期温度の入力項目を利用 して, 初期の要素密度を 0 にするか 1 にするかの条件（0/1）と, 要 素密度を変化させるか固定するかの条件 $(0 / 1)$ を設定している. こ の場合, 荷重が加わるスラブなど, 消えてはいけない要素では, 比 熱 1 , 初期温度 1 を与え, 要素が残ってほしくない空間部分の要素 では, 比熱 0 , 初期温度 1 を与える. また, 設計対象要素で, 初期 密度が 1 の場合は, 比熱 1 , 初期温度 0 を与え, 初期密度が 0 の場 合は, 比熱 0 , 初期温度 0 を与える. 以上で作成したデータをテキ ストデータとして出力し, これを本研究で作成したプログラムに読 み込んでいる. また, 最適化に必要なパラメータに関しては, Excel シート上に入力し, Excel のマクロ機能を利用して, 入出力データ名 の指定や解析の実行を行っている. なお，解形態の出力（表示）に は Micro AVS ${ }^{14)}$ を用いている.

なお, 本論文では, CA-IESO 法の有効性を検証するための比較解 として, CA-ESO 法の解析解も用いる. ただし, 文献 10,11)に示す CA-ESO 法では, (2), (3)式の影響半径による感度の平滑化を用いて いなかったため, ここでは， $b_{r}=b_{r}^{f}=1$ として同様の平滑化を用い る（荷重点および支持点の応力集中を緩和するため)。また，CA 法 の付加アルゴリズムは, CA-IESO 法と同じものを用いる（1 ステッ プの付加要素が増えすぎないようにするため). したがって, この場 合の CA-ESO 法と CA-IESO 法の違いは, 感度指標に Von Mises 応 力を用いるか, 要素ひずみエネルギーを用いるかと, $\eta_{E}{ }^{\left({ }^{k}\right)}$ の基準值 $\eta_{E}$ を与えるか, 要素除去率 $\lambda_{E}$ を与えて $\eta_{E}{ }^{(k)}$ をプログラム内で自動 計算するかにある. 


\section{3. 基本的な解析例}

まず，提案手法の有効性を検証するため, 文献 8,9)に示されてい る基本的例題の解析を行う。ただし，プリプロセッサに用いている VOXELCON の制約から，2 次元問題は，板厚方向を 2 要素で分割 し, 面外変形を拘束する (平面ひず夕仮定). また, 解析は領域全体 で行い, 対称問題に対しては, 設計変数に対称条件を与えている. なお，ここでは，大域的最適解近傍の解 15)が多くならないように， 目標要素数比を文献 8,9) より小さく設定している. また, ボクセル の大きさは $1 \mathrm{~cm} \times 1 \mathrm{~cm} \times 1 \mathrm{~cm}$ とし, ヤング係数は $20500 \mathrm{kN} / \mathrm{cm}^{2}$, ポ アソン比は 0.3 に統一している. なお, 本章の解析例では, 全要素 が要素密度の変化する設計対象要素となる。

Fig.1は, Example 1 (Ex.1)の解析モデルを示している.ただし, 荷重は， $Z$ 方向 3 節点に均等に与えている。 また, 図中には, 全要 素密度を 1 とした場合のひずみエネルギー分布（CA-IESO 法の感 度指標）と Von Mises 応力分布（CA-ESO 法の感度指標）を示して いる. ただし, 両分布は最大值が 1 になるように正規化し, その上 で，ひずみエネルギー分布は最大色（赤）の值を 0.01, Von Mises 応力分布は最大色の值を 0.1 で表示している. これらの図より, ひ ずみエネルギー分布に比較して, Von Mises 応力分布は, 相対比が 大きく，差異が捉えやすいことがわかる.

Fig. 3 は, 大域的最適解近傍の解を求めるために, 図中に示寸全設 計対象要素の初期密度を 1 とした初期形態（Case 1）から求めたパ ラメータ $\lambda_{E}$ に対するコンプライアンス最小解を示している.ただし， 目標要素数比 $\bar{V}_{r}$ は 0.1 とし, $N_{T}=250, N_{F}=0, \lambda_{E}^{f}=0.01, \lambda_{A}^{f}=0.01$, $b_{r}=b_{r}^{f}=1$ は共通としている. また, 図中に示寸 $C / C^{0}$ は, 各解の コンプライアンスと初期形態のコンプライアンス $C^{0}$ との比を示し, $N^{O P T}$ はコンプライアンス最小解が得られたステップ数を示す.

Fig.3 に示すように, この場合の解は， $\lambda_{E}=0.01$ の形状の上下の幅 がやや狭いが，他はほぼ同形状となることがわかる.

Fig.4 は, 図に示寸初期形態（Case 2）から求めたパラメータ $\lambda_{E}, \lambda_{A}$ に対するコンプライアンス最小解を示している. ただし, $\bar{V}_{r}=0.1, N_{T}=400, N_{F}=350, \lambda_{E}^{f}=0.01, \lambda_{A}^{f}=0.01, b_{r}=b_{r}^{f}=1$ は 共通としている. なお, 図中の $C^{0}$ は, Case 1 の初期形態のコンプ ライアンスを示寸. Fig.4 に示寸ように，この場合の解は，Fig.3の 解と比較して, 同位相になっているが, やや上下に狭まった形状に 収束し, コンプライアンスも Fig.3 の解と比較するとやや高いこと がわかる. また，このような問題では，除去率 $\lambda_{E}$ と付加率 $\lambda_{A}$ を高 目に設定寸ることで大域的最適解近傍の解に近づくことがわかる.

Fig.5 は, 図に示寸初期形態（Case 3）から求めたパラメータ $\lambda_{E}, \lambda_{A}$ に対するコンプライアンス最小解を示している. ただし, $\bar{V}_{r}=0.1, N_{T}=1000, N_{F}=950, \lambda_{E}^{f}=0.01, \lambda_{A}^{f}=0.01, b_{r}=b_{r}^{f}=1$ は 共通としている. Fig.5 に示すように, この場合の解は, パラメータ の設定次第では Fig.3 とは異なる形態に収束する。しかし, $\lambda_{E}=0.02, \lambda_{A}=0.04$ の場合は，上下方向の幅がやや広いが，Fig.3， Fig.4 と同位相・同形状の形態に収束寸ることがわかる. なお，この 問題では, 除去率 $\lambda_{E}$ を大きくすると, 解析途中で構造が切断され, 解が発散する場合があるため, 除去率 $\lambda_{E}$ は 0.02 以下に設定してい る. このような場合は, 付加率 $\lambda_{A}$ を大きく設定することで, よりコ ンプライアンスの低い解に収束させることができる。
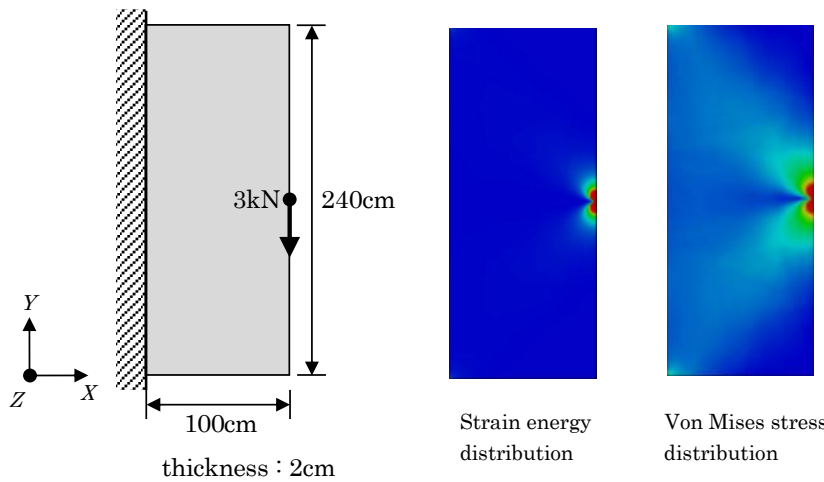

Strain energy distribution

Von Mises stress distribution

Fig.2 Analysis model of Example 1

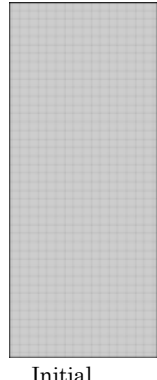

morphology

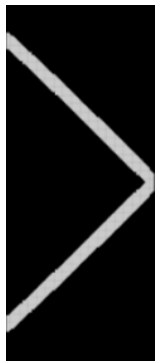

$\lambda_{E}=0.01$ $N^{O P T}=209$ $C / C^{0}=3.490$

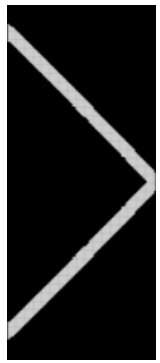

$\lambda_{E}=0.02$ $N^{O P T}=155$

$C / C^{0}=3.518$

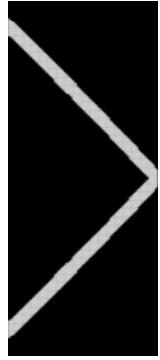

$\lambda_{E}=0.03$ $N^{O P T}=74$

$C / C^{0}=3.507$

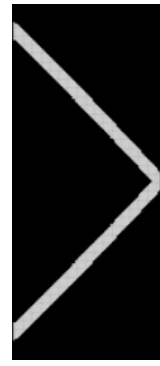

$\lambda_{E}=0.04$ $N^{O P T}=59$
Fig.3 Optimal solutions by CA-IESO (Case 1)

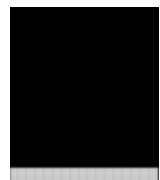

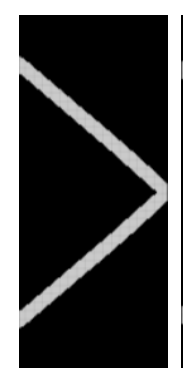

$\lambda_{E}=0.04$ $\lambda_{A}=0.04$ $N^{O P T}=363$ $C / C^{0}=3.585$

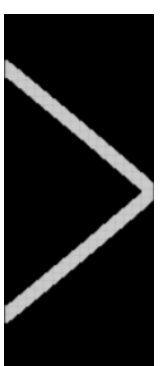

$\lambda_{E}=0.05$ $\lambda_{A}=0.05$ $N^{O P T}=321$ $C / C^{0}=3.594$

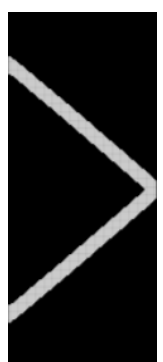

$\lambda_{E}=0.06$ $\lambda_{A}=0.06$ $N^{O P T}=334$ $C / C^{0}=3.562$

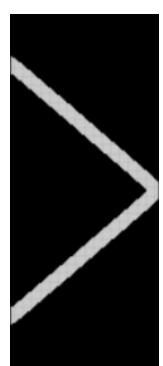

$\lambda_{E}=0.07$ $\lambda_{A}=0.07$ $N^{O P T}=342$ $C / C^{0}=3.543$
Fig.4 Optimal solutions by CA-IESO (Case 2)

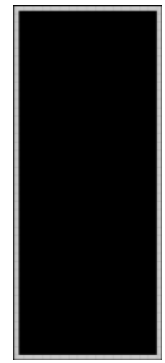

Initial morphology

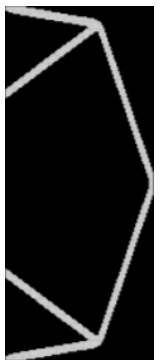

$\lambda_{E}=0.01$ $\lambda_{A}=0.01$ $N^{O P T}=995$

$C / C^{0}=8.574$

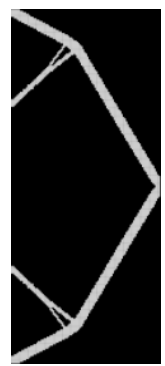

$\lambda_{E}=0.01$ $\lambda_{A}=0.04$ $N^{O P T}=989$ $C / C^{0}=4.815$

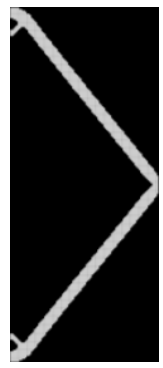

$\lambda_{E}=0.02$ $\lambda_{A}=0.02$ $N^{O P T}=988$ $C / C^{0}=3.914$

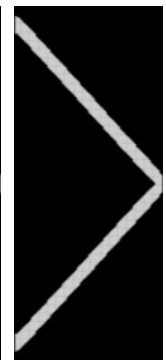

$\lambda_{E}=0.02$ $\lambda_{A}=0.04$ $N^{O P T}=951$ $C / C^{0}=3.616$
Fig.5 Optimal solutions by CA-IESO (Case 3) 
Fig.6 は, Case 1〜Case 3 の初期形態に対する CA-ESO 法による 最適解を示している. 図には, $\eta_{E}$ を 0.1 刻みで手動で探查し, 最小 コンプライアンスが得られた解を示している. なお, Case 3 では参 考のため, 途中ステップ ( $\left.N^{\text {STEP }}\right)$ の解も示している. ただし, $\bar{V}_{r}=0.1$ とし， $N_{T}, N_{F}$ と $\lambda_{A}^{f}$ は, Fig.3〜Fig.5 の解析で用いたもの と同じにしている. Fig.6より, CA-ESO 法の解も, Fig.3〜Fig.5に 示した CA-IESO の解とほぼ同位相・同形状となっていることがわ かる. なお, Case 3 では, $\eta_{E}$ の值を調整しても, これよりコンプ ライアンスの低い解は得られなかった。
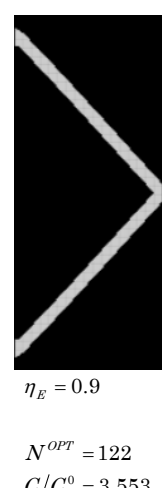

$C / C^{0}=3.553$

[Case 1]

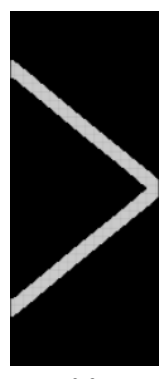

$\eta_{E}=0.9$ $\lambda_{A}=0.07$ $N^{\text {OPT }}=376$ $C / C^{0}=3.729$

[Case 2]

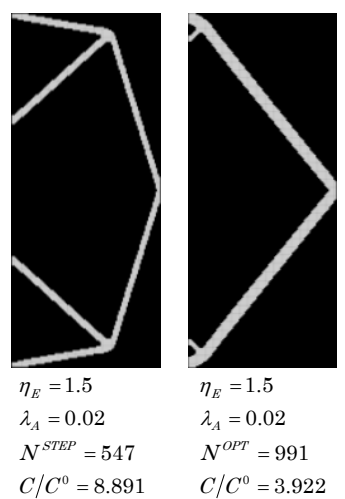

[Case 3]
Fig.6 Optimal solutions by CA-ESO

Fig.7 は, Ex. 2 の解析モデルを示している.ただし, 荷重は $Z$ 方 向 3 節点に均等に与えている。 また, 図中には, 全要素密度を 1 と した場合のひずみエネルギー分布と Von Mises 応力分布を示してい る. ただし, 両分布は最大值が 1 になるように正規化し, その上で, ひずみエネルギー分布は最大色（赤）の值を 0.01, Von Mises 応力 分布は最大色の值を 0.1 で表示している. 図より, この場合もVon Mises 応力分布の方が，相対比が大きいことがわかる.

Fig.8 は, 大域的最適解近傍の解を求めるために, 全設計対象要素 の初期密度を 1 とした初期形態（Case 4）から求めたパラメータ $\lambda_{E}, b_{r}, b_{r}^{f}$ に対するコンプライアンス最小解を示している. ただし, $\bar{V}_{r}=0.2$ とし $, N_{T}=200, N_{F}=0, \lambda_{E}^{f}=0.01, \lambda_{A}^{f}=0.01$ は共通とし ている. Fig.8に示すように, この場合は, パラメータの設定によっ て，概ね 2 種の位相の解が得られ，それぞれの位相において同様の コンプライアンスでやや形状が異なる解が得られることがわかる.

Fig.9 は, 図に示寸初期形態（Case 5) から求めたパラメータ $\lambda_{E}, \lambda_{A}, b_{r}, b_{r}^{f}$ に対するコンプライアンス最小解を示している. ただ し, $\bar{V}_{r}=0.2, N_{T}=400, N_{F}=350, \lambda_{E}^{f}=0.01, \lambda_{A}^{f}=0.01$ は共通と している. なお， $C^{0}$ は， Case 4 の初期形態のコンプライアンスを 示す. Fig.9 に示すように, この場合の解は, Fig.8 の上段の解と同 位相となっており, パラメータの設定次第では, Fig.8 の解よりもさ らに低いコンプライアンスの解が得られることがわかる.

Fig.10 は, 図に示寸初期形態 (Case 6) から求めたパラメータ $\lambda_{E}, \lambda_{A}, b_{r}, b_{r}^{f}$ に対するコンプライアンス最小解を示している. ただ し, $\bar{V}_{r}=0.2, N_{T}=1000, N_{F}=950, \lambda_{E}^{f}=0.01, \lambda_{A}^{f}=0.01$ は共通 としている. Fig.10 に示すように, この場合は, 位相は Fig.8の上 段と同じ位相になるが，形状は異なる解に収束していることがわか

る.これはコンプライアンスの值から見て局所最適解であり, 初期 形態よっては，パラメータをいかに調整しても局所最適解に陥るこ ともあることがわかる。
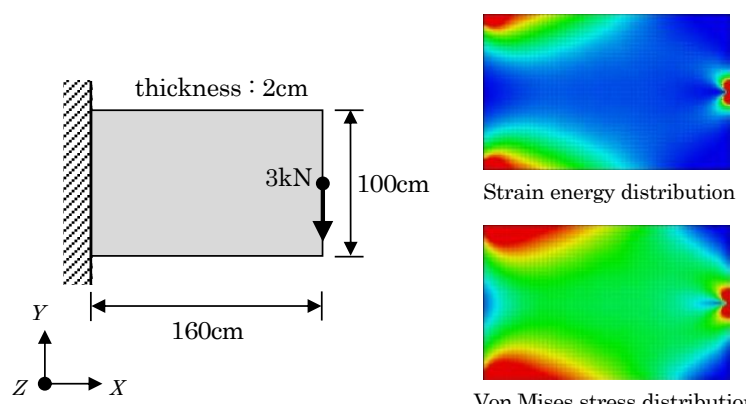

Fig.7 Analysis model of Example 2

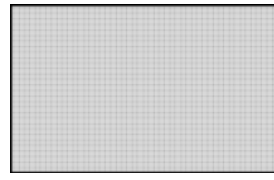

Initial morphology

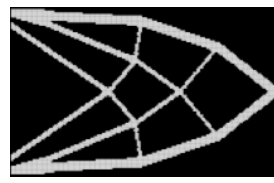

$\lambda_{E}=0.02, b_{r}=1, b_{r}^{f}=1$

$N^{O P T}=88, C / C^{0}=3.696$

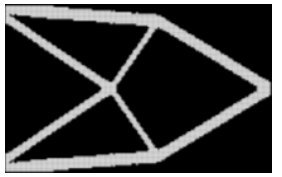

$\lambda_{E}=0.02, b_{r}=3, b^{f}=3$ $N^{O P T}=118, C / C^{0}=3.67$

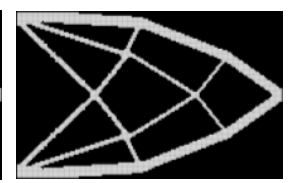

$\lambda_{E}=0.03, b_{r}=1, b_{r}^{f}=1$ $N^{O P T}=53, C / C^{0}=3.572$

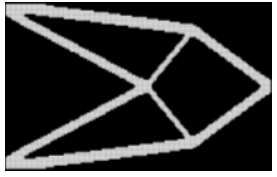

$\lambda_{E}=0.04, b_{r}=3, b_{r}^{f}=3$ $N^{O P T}=41, C / C^{0}=3.578$

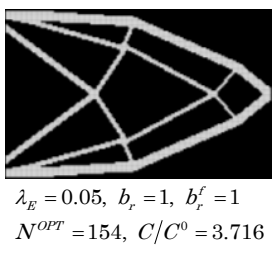

(Case 4)

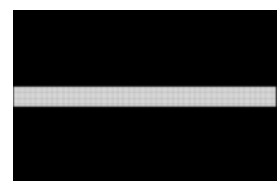

Initial morphology

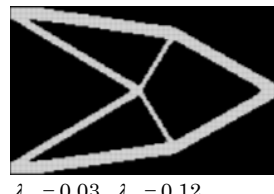
$b_{r}=1, b_{r}^{t}=1$ $N^{O P T}=332, C / C^{0}=3.461$
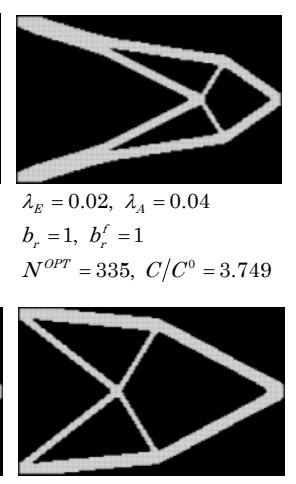

$\lambda_{E}=0.04, \lambda_{A}=0.16$ $b_{r}=3, b_{r}^{t}=3$

$N^{O P T}=360, C / C^{0}=3.531$
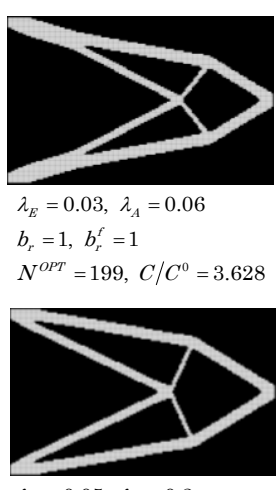

$\lambda_{E}=0.05, \lambda_{A}=0.2$ $b_{r}=1, b_{r}^{f}=1$ $N^{O P T}=300, C / C^{0}=3.611$
Fig. 9 Optimal solutions by CA-IESO (Case 5 )

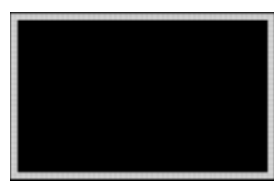

Initial morphology

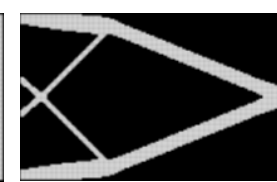

$\lambda_{E}=0.02, \lambda_{A}=0.04$ $b_{r}=1, b_{r}^{f}=1$ $N^{O P T}=335, C / C^{0}=3.848$

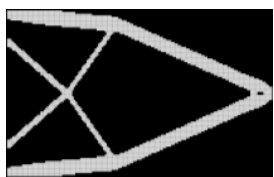

$\lambda_{E}=0.05, \lambda_{A}=0.2$ $b_{r}=1, b_{r}^{f}=1$ $N^{\text {OPT }}=837, C / C^{0}=3.638$
Fig.10 Optimal solutions by CA-IESO (Case 6) 
Fig.11 は, Case 4〜Case 6 の初期形態に対する CA-ESO 法によ る最適解を示している. 図には, $\eta_{E}$ を 0.1 刻みで探査し, 最小コン プライアンスが得られた解を示している.ただし， $\bar{V}_{r}=0.2$ とし， $N_{T}, N_{F}$ と $\lambda_{A}^{f}$ は, Fig.8 Fig.10の解析で用いたものと同じにして いる. Fig.11 より, CA-ESO 法の解も, Fig.8～Fig.10 に示した解 のいくつかとほぼ同位相・同形状となっていることがわかる.なお，

Case 4 では, $\eta_{E}$ の值を調整しても, Fig.8 の下段のような位相形態 は得られなかった。 また, Fig.8～Fig.10 の解と Fig.11 の解のコン プライアンスを比較すると，いずれも CA-IESO 法の方がより低い コンプライアンスの解が得られていることがわかる.

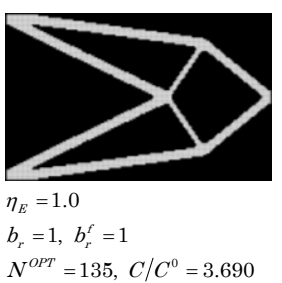

[Case 4]

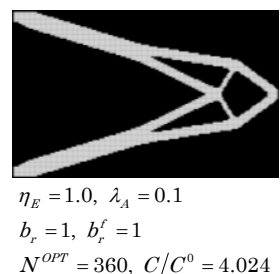

[Case 5]

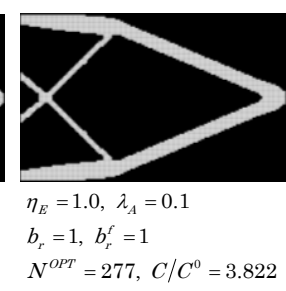

[Case 6]
Fig. 11 Optimal solutions by CA-ESO

Fig.12は，Ex. 3の解析モデルを示している．ただし，荷重は $Z$ 方 向 3 節点に均等に与え, 支持点も $Z$ 方向 3 節点を拘束している. また, 図中には, 全要素密度を1とした場合のひずみエネルギー分布とVon Mises応力分布を示している. ただし，両分布は最大值が1になるよ うに正規化し，その上で，ひずみエネルギー分布は最大色（赤）の 值を0.05, Von Mises応力分布は最大色の值を $0.2 て ゙$ 表示している.

Fig.13 は, 大域的最適解近傍の解を求めるために, 全設計対象要 素の初期密度を 1 とした初期形態（Case 7) から求めたパラメータ $\lambda_{E}, b_{r}, b_{r}^{f}$ に対するコンプライアンス最小解を示している. ただし, $\bar{V}_{r}=0.25$ とし $, N_{T}=200, N_{F}=0, \lambda_{E}^{f}=0.01, \lambda_{A}^{f}=0.01$ は共通と している. Fig.13 に示すように, $b_{r}=b_{r}^{f}=1$ とした場合は, 多様な 位相形態が得られ, $b_{r}=b_{r}^{f}=3$ とした場合は, 同位相で微妙に形状 が異なる解形態が得られることがわかる.

Fig.14 は, 図に示寸初期形態 (Case 8) から求めたパラメータ $\lambda_{E}, \lambda_{A}, b_{r}, b_{r}^{f}$ に対するコンプライアンス最小解を示している. ただ し, $\bar{V}_{r}=0.25, N_{T}=1000, N_{F}=950, \lambda_{E}^{f}=0.01, \lambda_{A}^{f}=0.01$ は共通 としている. なお， $C^{0}$ は, Case 7 の初期形態のコンプライアンス を示す. Fig.14 に示すように, この場合の解は, Fig.13 の右側の解 と同位相となっており, パラメータの設定によっては, Fig.13に示 寸解よりも低いコンプライアンスの解が得られることがわかる.

Fig.15 は, 図に示寸初期形態 (Case 9) から求めたパラメータ $\lambda_{E}, \lambda_{A}, b_{r}, b_{r}^{f}$ に対するコンプライアンス最小解を示している. ただ し, $\bar{V}_{r}=0.25, N_{T}=1000, N_{F}=950, \lambda_{E}^{f}=0.01, \lambda_{A}^{f}=0.01$ は共通 としている. Fig.15 に示すように, この場合の解は, Fig.13 にはな い位相形態（局所最適解）に収束する場合もあるが，パラメータの 設定によっては，大域的最適解近傍の解に近い解も得られることが わかる. なお, この問題でも, 除去率 $\lambda_{E}$ を大きくすると, 解析途中 で構造が切断され解が発散する場合があるため, $\lambda_{E}$ は小さい值に設 定している.このような場合も, 付加率 $\lambda_{A}$ を大きく設定することで, よりコンプライアンスの低い解が得られることがわかる.

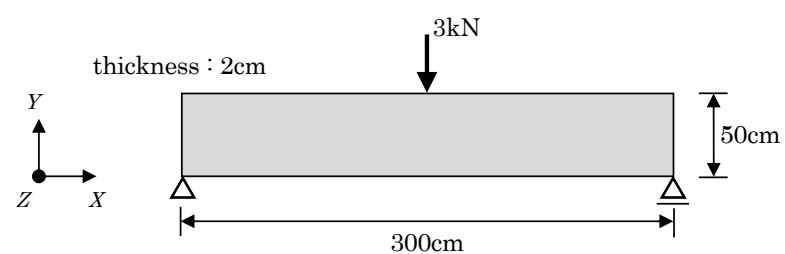

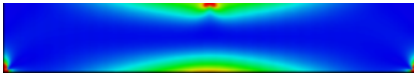

Strain energy distribution

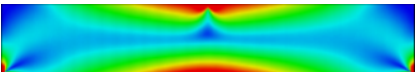

Von Mises stress distribution

Fig.12 Analysis model of Example 3

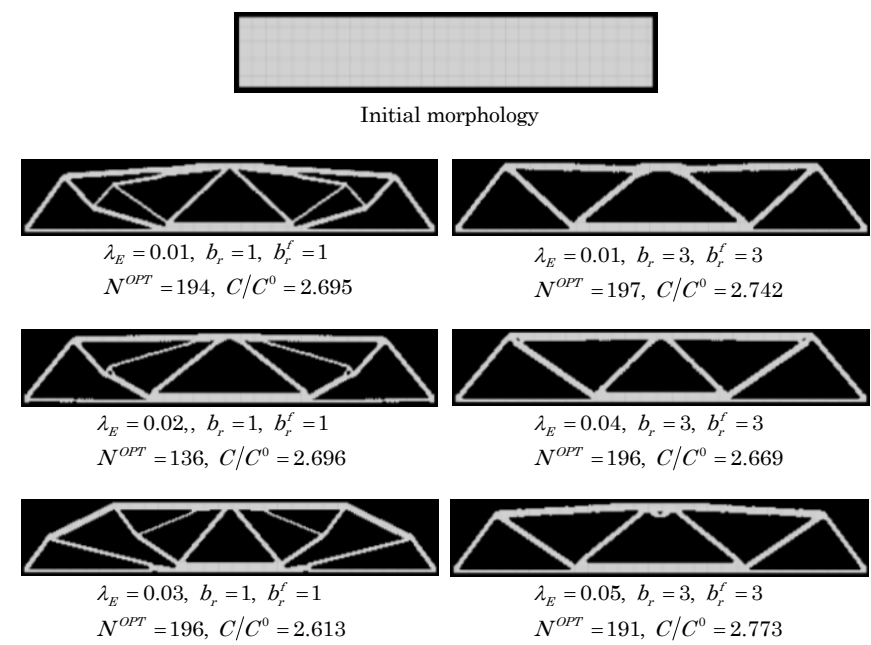

Fig. 13 Optimal solutions by CA-IESO (Case 7)

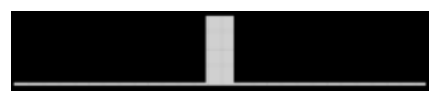

Initial morphology

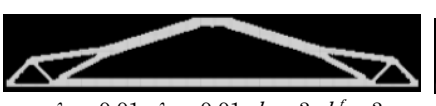

$\lambda_{E}=0.01, \lambda_{A}=0.01, b_{r}=3, b_{r}^{f}=3$ $N^{O P T}=630, C / C^{0}=3.490$

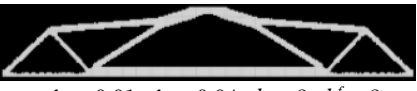

$\lambda_{E}=0.01, \lambda_{A}=0.04, b_{r}=3, b_{r}^{f}=3$

$N^{O P T}=956, C / C^{0}=2.987$

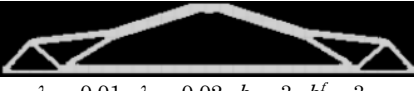

$\lambda_{E}=0.01, \lambda_{A}=0.02, b_{r}=3, b_{r}^{f}=3$ $N^{\text {OPT }}=912, C / C^{0}=3.301$

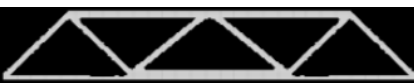

$\lambda_{E}=0.01, \lambda_{A}=0.1, b_{r}=3, b_{r}^{f}=3$ $N^{O P T}=840, C / C^{0}=2.523$
Fig.14 Optimal solutions by CA-IESO (Case 8)

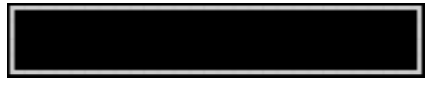

Initial morphology

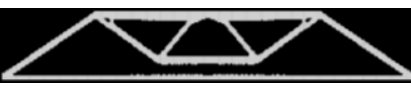

$\lambda_{E}=0.01, \lambda_{A}=0.01, b_{r}=3, b_{r}^{f}=3$ $N^{O P T}=450, C / C^{0}=3.003$

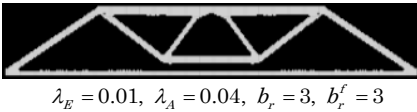
$N^{O P T}=737, C / C^{0}=2.806$

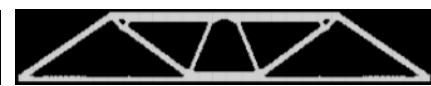

$\lambda_{E}=0.01, \lambda_{A}=0.02, b_{r}=3, b_{r}^{f}=3$ $N^{O P T}=921, C / C^{0}=2.770$

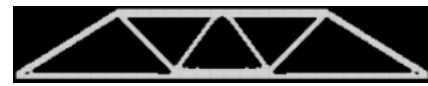

$\lambda_{E}=0.01, \lambda_{A}=0.1, b_{r}=3, b_{r}^{f}=3$ $N^{O P T}=737, C / C^{0}=2.571$
Fig.15 Optimal solutions by CA-IESO (Case 9) 
Fig.16 は, Case 7〜Case 9 の初期形態に対する CA-ESO 法によ る最適解を示している. 図には, $\eta_{E}$ を 0.1 刻みで探査し, 最小コン プライアンスが得られた解を示している.ただし， $\bar{V}_{r}=0.25$ とし， $N_{T}, N_{F}$ と $\lambda_{A}^{f}$ は, Fig.13〜 Fig.15 の解析で用いたものと同じにして いる. Fig.16より, Case 7 について, Fig.13 に示す解と同位相の ものは得られていないが, Case 8, 9 については, Fig.14, Fig.15 と ほぼ同位相・同形状のものが得られていることがわかる.なお, Case 7 では, $\eta_{E}$ の值を調整しても, 図に示寸解よりもコンプライアンス の低い解は得られなかった。

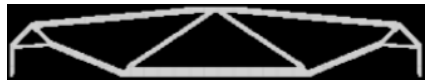 \\ $\eta_{E}=1.0, b_{r}=1, b_{r}^{f}=1$ \\ $N^{\text {OPT }}=167, C / C^{0}=3.192$} [Case 7]

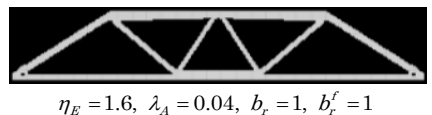

$N^{O P T}=865, C / C^{0}=2.737$

[Case 9]

Fig.16 Optimal solutions by CA-ESO

Fig.16 は, Ex. 4 の解析モデルを示している.ただし, 荷重は自 由端 $Y Z$ 面中央の $3 \times 3$ 節点に均等に与えている. なお, この解析例 では，CA-IESO 法と CA-ESO 法との比較は割愛している.

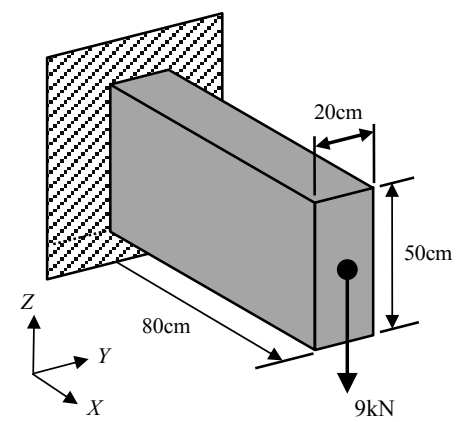

Fig.17 Analysis model of Example 4

Fig.18 は, 大域的最適解近傍の解を求めるために, 全設計対象要 素の初期密度を 1 とした初期形態（Case 10）から求めたパラメー 夕 $\lambda_{E}, b_{r}, b_{r}^{f}$ に対するコンプライアンス最小解を示している.ただし, $\bar{V}_{r}=0.1$ とし, $N_{T}=250, N_{F}=0, \lambda_{E}^{f}=0.01, \lambda_{A}^{f}=0.01$ は共通とし ている. Fig.18に示すように, パラメータの設定により, 多様な形 態が得られることがわかる，このように，3 次元問題になると，同 じ目標要素数比に対して, 多数の大域的最適解近傍の解が存在する.

Fig.19 は, 図に示寸初期形態（Case 11）から求めたパラメータ $\lambda_{E}, \lambda_{A}, b_{r}, b_{r}^{f}$ に対するコンプライアンス最小解を示している. ただ し, $\bar{V}_{r}=0.1, N_{T}=400, N_{F}=350, \lambda_{E}^{f}=0.01, \lambda_{A}^{f}=0.01$ は共通と している. なお， $C^{0}$ は, Case 10 の初期形態のコンプライアンスを 示寸. Fig.19 に示寸ように, この場合の解は, Fig.18 中に同様の位 相はあるが, やや上下方向に細い形状（局所最適解）に収束するこ とがわかる。

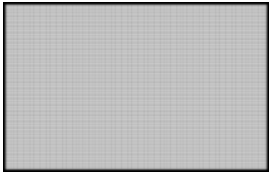

Side view

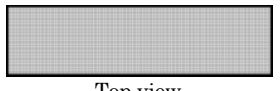

Top view

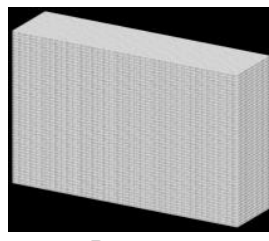

Perspective

Initial morphology

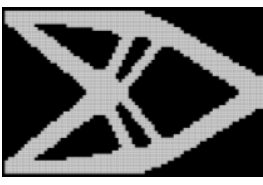

Side view

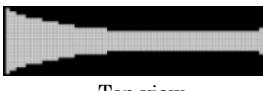

Top view

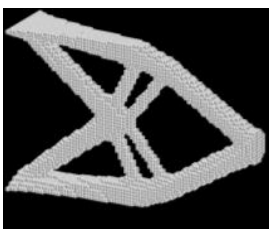

Perspective $N^{\text {OPT }}=218, C / C^{0}=6.065$
$\lambda_{E}=0.01, b_{r}=3, b_{r}^{f}=3$

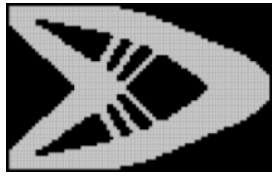

Side view

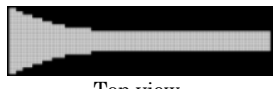

Top view

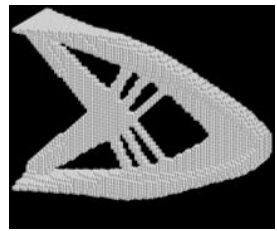

Perspective

$\lambda_{E}=0.01, b_{r}=1, \quad b_{r}^{f}=1$

$N^{O P T}=220, C / C^{0}=5.815$

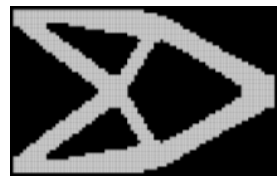

Side view

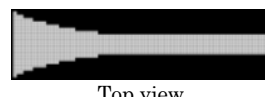

Top view

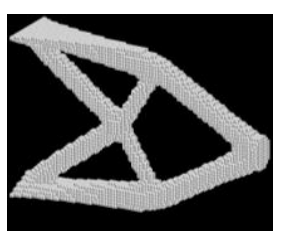

Perspective

$\lambda_{E}=0.04, b_{r}=3, b_{r}^{f}=3$

$N^{O P T}=65, C / C^{0}=6.130$

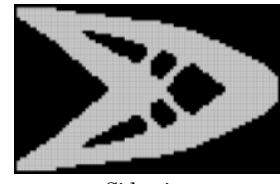

Side view

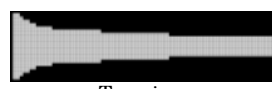

Top view

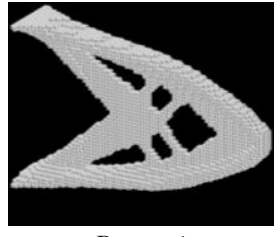

Perspective

$\lambda_{E}=0.04, b_{r}=1, b_{r}^{f}=1$

$N^{O P T}=56, C / C^{0}=5.854$

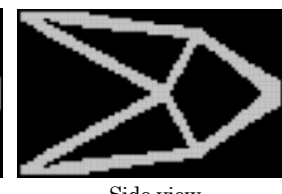

Side view
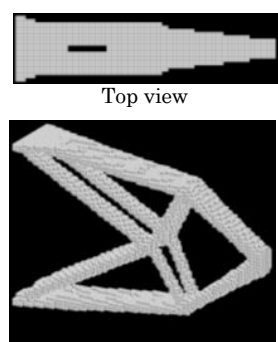

Perspective

$\lambda_{E}=0.1, b_{r}=1, b_{r}^{f}=1$ $N^{O P T}=225, C / C^{0}=6.420$
Fig.18 Optimal solutions by CA-IESO (Case 10)

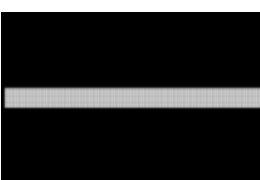

Side view

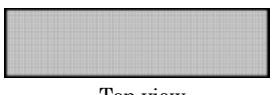

Top view

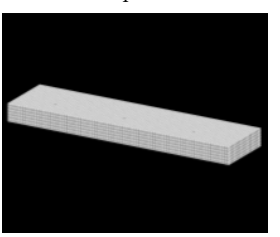

Perspective

Initial morphology

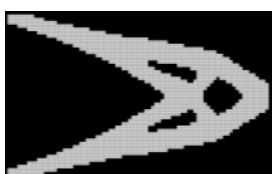

Side view

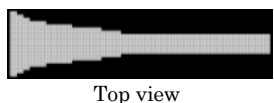

Top view

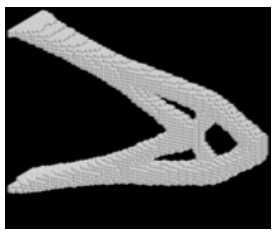

Perspective

$\lambda_{E}=0.03, \lambda_{A}=0.12$ $b_{r}=1, b_{r}^{f}=1$ $N^{O P T}=320, C / C^{0}=6.411$

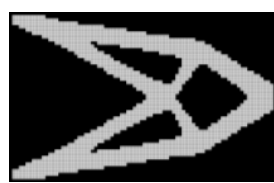

Side view
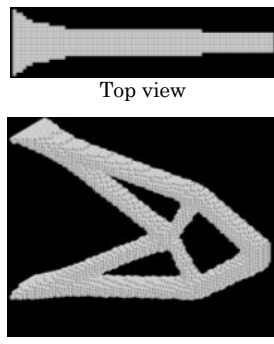

Perspective

$\lambda_{E}=0.05, \lambda_{A}=0.2$ $b_{r}=1, b_{r}^{f}=1$ $N^{O P T}=352, C / C^{0}=6.130$
Fig.19 Optimal solutions by CA-IESO (Case 11) 
Fig.20は, 図に示寸初期形態（Case 12）から求めたパラメータ $\lambda_{E}, \lambda_{A}, b_{r}, b_{r}^{f}$ に対するコンプライアンス最小解を示している. ただ し, $\bar{V}_{r}=0.1, N_{T}=400, N_{F}=350, \lambda_{E}^{f}=0.01, \lambda_{A}^{f}=0.01$ は共通と している. Fig.20に示すように, この場合の解は, 2 次元問題の Fig.10と同様の局所最適解に収束することがわかる.

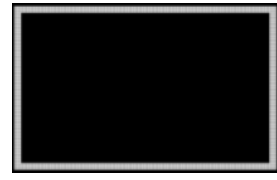

Side view

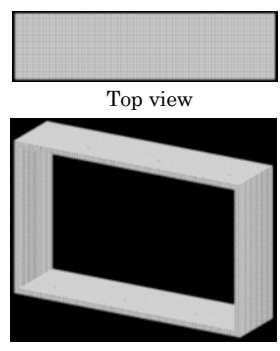

Perspective

Initial morphology

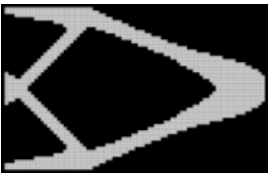

Side view

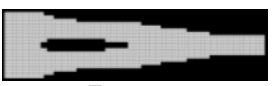

Top view

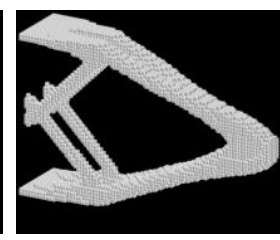

Perspective

$b_{r}=1, b_{r}^{f}=1$

$N^{O P T}=363, C / C^{0}=6.654$
$\lambda_{E}=0.02, \lambda_{A}=0.2$

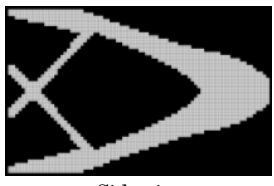

Side view

Top view

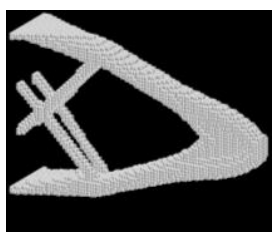

Perspective

$\lambda_{E}=0.05, \lambda_{A}=0.5$ $b_{r}=1, b_{r}^{f}=1$

$N^{O P T}=364, C / C^{0}=6.406$

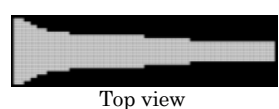

Fig.20 Optimal solutions by CA-IESO (Case 12)

以上の解析例から, CA-IESO法では, 全設計対象要素の初期密度 を1とした初期形態からは, 多様な大域的最適解近傍の解が得られ, 要素数の少ない初期形態からは, 比較的シンプルな大域的最適解近 傍の解に収束すること, また, 初期形態によっては, 局所最適解に 陥ることもあることがわかった，また，計算時間に関しては，少な い要素数の初期形態から求める方が 1 ステップあたりの解析時間は 速いが, 大域的最適解近傍の解に至るまでのステップ数が多くなる ため, 計算時間の節約には結びつかないこともわかった.

また， 2 次元問題におけるCA-ESO法との比較により, CA-ESO 法によっても，CA-IESO法と類似した解形態を得ることは可能だが， $\eta_{E}$ の調整だけでは, 探査範囲が限定され, CA-IESO法ほど多様な 最適解は得られないことがわかった。 また, 同様の最適形態では, CA-IESO法の方がより低いコンプライアンスの解が得られること もわかった。 これは, CA-ESO法の感度指標がコンプライアンスの 峳密な感度ではなく, Von Mises応力であるためと考えられる.

\section{4. 応用的な解析例}

次に, 応用的解析例として, 鉛直荷重と地震力を受けるスラブを 支持する構造体の形態創生を試みる. Fig.21は, このような例題 (Ex. 5）の解析モデル（平面図, 立面図, 初期形態透視図）を示す. 荷重 は, 床スラブ表面節点に均等な鉛直荷重 (各節点 $1 \mathrm{kN})$ とその 0.2 倍 のX,Y 2 方向の均等な水平荷重を加えている. なお, この場合, 最適 化の各ステップで 3 回の構造解析が行われ, それぞれの荷重に対し て得られた要素ひずみエネルギーの総和から各要素の感度指標が計 算される2).また, ボクセルの大きさは $1 \mathrm{~cm} \times 1 \mathrm{~cm} \times 1 \mathrm{~cm}$ と, ヤン グ係数は $20500 \mathrm{kN} / \mathrm{cm}^{2}$, ポアソン比は 0.3 とている. 境界条件は, 図中の平面図に示寸ように直方体固定設計領域底面の $8 \times 8$ 要素の 9 $\times 9$ 節点を $X Y Z$ 万向に拘束するものとする. なお, これらの拘束点は, 非対称の形態が得られるように, 意図的にスラブの対角線から少し ずらした位置に設定している，また，荷重が加わるスラブ面（厚さ $1 \mathrm{~cm} ）$ の要素は, 要素密度が変化しない設計固定要素とし, それ以 外の全要素は, 要素密度が変化する設計対象要素としている.なお, Fig.21の右下に示寸初期形態 (Case 14) では, 図に示す柱部分の初 期密度を 1 とし，それ以外の初期密度を 0 に設定している。

Fig.22は, 大域的最適解近傍の解を求めるために, 全設計対象要 素の初期密度を1とした初期形態（Case 13）から求めたコンプライ アンス最小解を示している. ただし， $\bar{V}_{r}=0.06$ とし, $N_{T}=250$, $N_{F}=0, \lambda_{E}^{f}=0.01, \lambda_{A}^{f}=0.01, b_{r}=b_{r}^{f}=1$ は共通としている. 図に は，それぞれの解に対して，Fig.22の平面図の右上から見た方向と 左下から見た方向の透視図を示している.
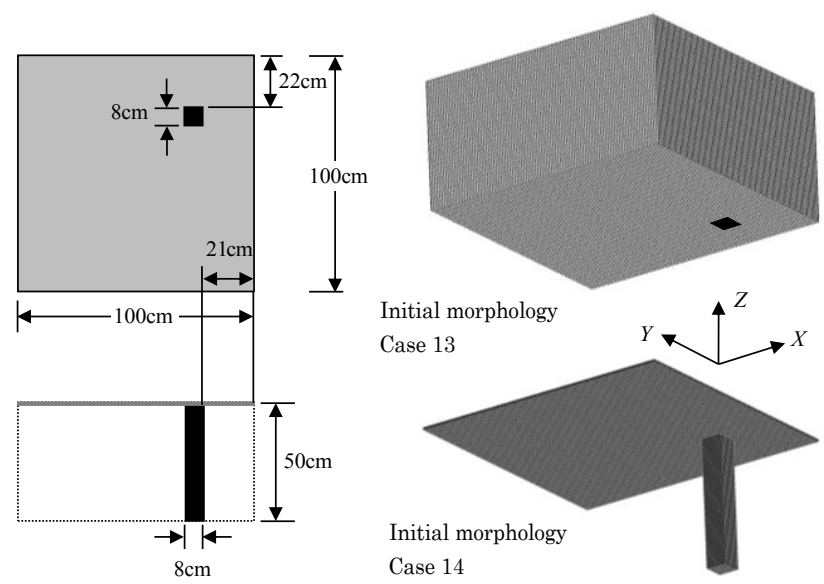

Fig.21 Analysis model of Example 5

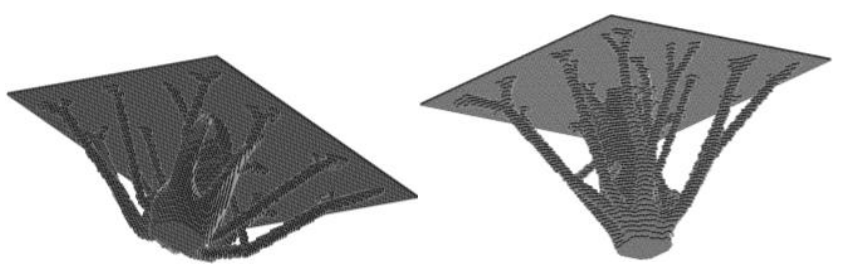

$\lambda_{E}=0.02 \quad N^{O P T}=181, C / C^{0}=1.354$

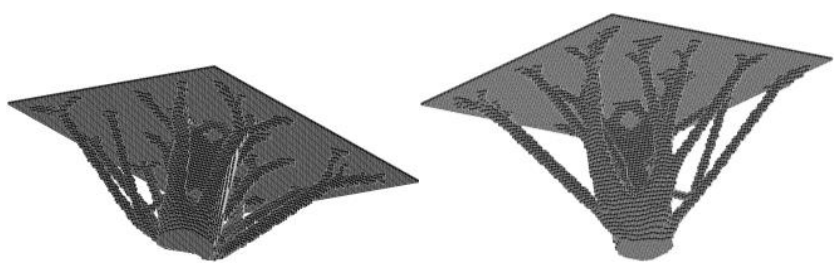

$\lambda_{E}=0.05 \quad N^{O P T}=227, C / C^{0}=1.345$

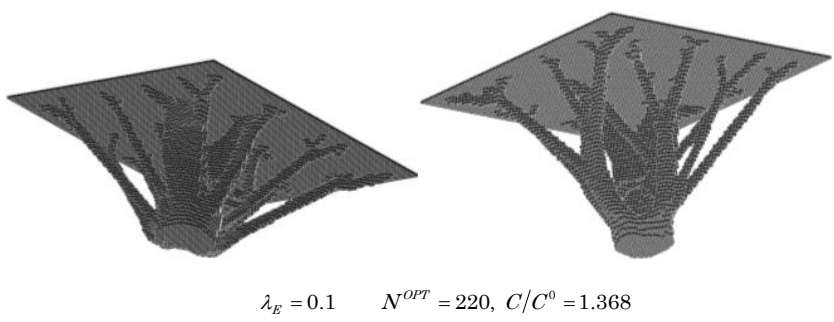

Fig.22 Optimal solutions by CA-IESO (Case 13) 
Fig.22より， $\lambda_{E}$ を変化させることで, 枝分かれが微妙に異なる複 数の最適解が得られることがわかる. また, $b_{r}=b_{r}^{f}=1$ でも, 比較 的シンプルな形態が得られている. これは, 目標要素数に達した後 の仕上過程でよりシンプルな形態に進化したものと考えられる.

Fig.23は, このことを確かめるために, Fig.22に示す $\lambda_{E}=0.02$ の場 合について, 仕上過程の進化の様子を示している. 図に示すように, 徐々にシンプルな形態に進化していることがわかる.したがって, 本手法では, 影響半径倍率 $b_{r}, b_{r}^{f}$ を大きくしなくても, 比較的シン プルな形態に収束する. このような点は, 文献1,2)で提案したIESO 法（十仕上アルゴリズム）とは異なる特徵と言える.
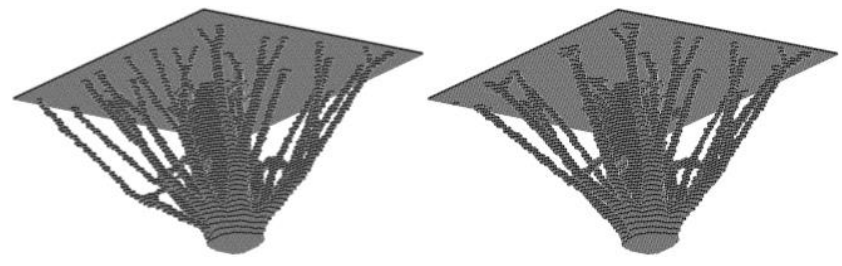

$N^{\text {STEP }}=101, C / C^{0}=1.410$

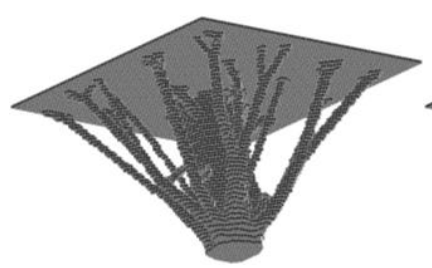

$N^{\text {STEP }}=140, C / C^{0}=1.364$

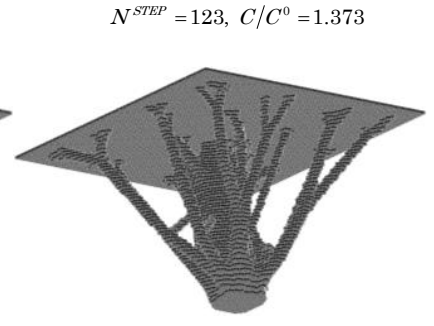

$N^{O P T}=181, C / C^{0}=1.354$
Fig.23 Optimization process by CA-IESO (Case 13: $\lambda_{E}=0.02$ )

Fig.24は, Fig.21の右下に示す初期形態 (Case 14) から求めたコ ンプライアンス最小解を示している.ただし， $\bar{V}_{r}=0.06$ とし， $\lambda_{E}^{f}=0.01, \lambda_{A}^{f}=0.01$ は共通としている. それ以外のパラメータは, 図に示寸とおりである.ただし, 図中の $C^{0}$ は, Case 13の初期形態 のコンプライアンスを示す. Fig.24の上段の解より, 最適化のステ ップ数は増えるが, Case 14の初期形態からも, Fig.22に示寸解に近 い解が得られることがわかる. また, 下段の解より, 影響半径倍率 を大きくすることで，コンプライアンスはやや高くなるが，よりシ ンプルな形態が得られることがわかる. また, Fig.25は, Fig.24の 下側の解の進化過程を示している. 図に示寸ように, 初期形態から 樹木が成長するようにゆっくりと進化していることがわかる.

次に, Case 13の初期形態による解析（ $\lambda_{E}=0.05$ の場合）とCase 14 の初期形態による解析（ $b_{r}=b_{r}^{f}=1$ の場合）の100ステップまで の解析時間を比較すると, Case 13の場合が15時間8分 (CPU:Core i9 9900K), Case 14の場合が10時間40分で, Case14の計算時間の 方が短いが, Case 13の250ステップの解析時間は36時間52分であっ たのに対し, Case 14の400ステップの解析時間は41時間32分と, 卜 ータルの解析時間はCase 13の方が短くなっている.したがって, 要 素数が少ない初期解から最適解を求めることが必ずしも計算効率の 改善には結びつかないことがわかった。 また, 有限要素解析におけ る計算効率は, 要素数だけでなく, 連立方程式の解法に用いている 前処理付き共役勾配法の反復回数にも依存する. 寸なわち, 最適化 問題では, 反復解法の初期解として前ステップの解を用いるため,
最適化の過程で解が大きく変化すれば，共役勾配法の反復回数が増 える.したがって，最適化のパラメータによっても，計算時間は変 化することになる.

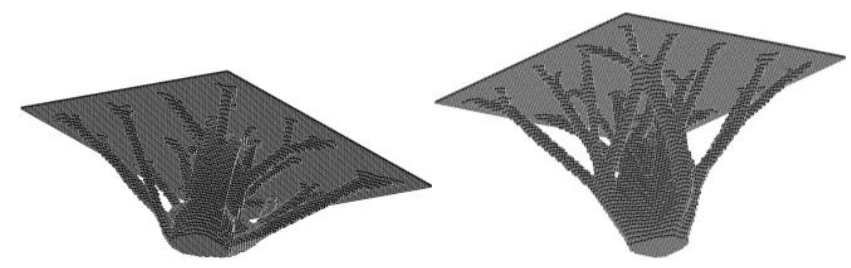

$N_{T}=400, N_{F}=350, \lambda_{E}=0.05, \lambda_{A}=0.1, b_{r}=1, \lambda_{E}^{f}=0.01, \lambda_{A}^{f}=0.01, b_{r}^{f}=1$ $N^{O P T}=376, C / C^{0}=1.367$

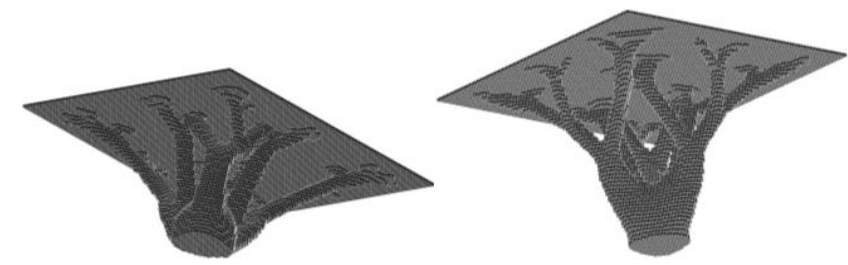

$N_{T}=300, N_{F}=200, \lambda_{E}=0.05, \lambda_{A}=0.1, b_{r}=5, \lambda_{E}^{f}=0.01, \lambda_{A}^{f}=0.02, b_{r}^{f}=3$ $N^{\text {OPT }}=298, C / C^{0}=1.517$

Fig.24 Optimal solutions by CA-IESO (Case 14)
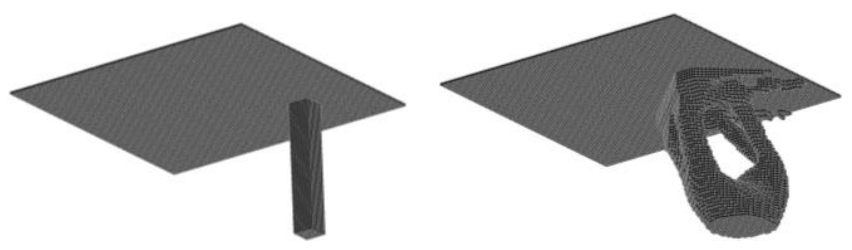

$N^{\text {STEP }}=0 \quad C / C_{0}=243 . .4, \quad V_{r}=0.026$
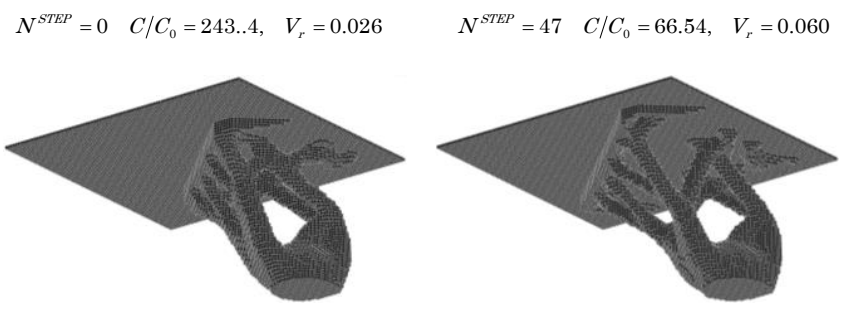

$N^{\text {STEP }}=97 \quad C / C_{0}=21.00, \quad V_{r}=0.060$ $N^{\text {STEP }}=148 \quad C / C_{0}=8.172, \quad V_{r}=0.060$
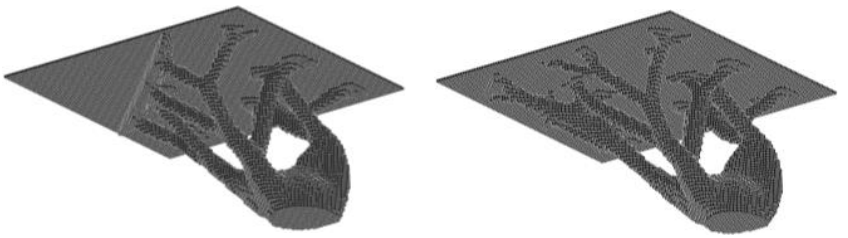

$N^{\text {STEP }}=197 \quad C / C_{0}=3.665 \quad V_{r}=0.060$

$N^{O P T}=298 \quad C / C_{0}=1.517, \quad V_{r}=0.060$

Fig.25 Optimization process by CA-IESO (Case $14: b_{r}=5$ )

5. まとめ

本論文では, 多様な初期形態から最適解を求めることができる CA-IESO法を提案し, その有効性を検証した。 その結果, 以下の知 見が得られた。

（1）全設計対象要素の初期密度を 1 とした初期形態からは，主に除 去率 $\lambda_{E}$ と影響半径倍率 $b_{r}$ の設定により，コンプライアンスの 低い（剛性の高い）複数の大域的最適解近傍の解が得られる. 
（2）要素数の少ない初期形態から進化させた場合は, 主に $\lambda_{E}$ と $\lambda_{A}$ の設定により, 大域的最適解近傍の解が得られる。しかし, 初 期形態の形状によっては, 最適化のパラメータをいかに調整し ても局所最適解に陥ることもある.

(3) 2 次元問題における提案手法 (CA-IESO法) と従来法 (CA-ESO 法）との比較により, 従来法によっても, 提案手法と類似した 解形態は得られるが, 従来法のパラメータ $\eta_{E}$ の調整だけでは 探査範囲が限定され，提案手法ほど多様な解形態は得られない。 また, 同位相・同形状の解では, 提案手法で得られた解の方が, コンプライアンスはより低くなる.

（4）鉛直荷重と地震力を受ける床スラブを支える構造体の形態創 生例では, 全設計対象要素の初期密度を 1 とした初期形態から 求めた解も, 少ない要素数の初期形態から求めた解も, 樹木の ような有機的形態が得られる. また, 少ない要素数の初期形態 から求める場合は, 初期形態からの進化過程が観察できるため, 初期形態を修正するような問題ではより有効と考えられる. ま た, 提案手法では, 全設計対象要素の初期密度を 1 とした初期 形態の場合も，仕上過程でよりシンプルな形態に進化する.

（5）計算効率に関しては, 要素数の少ない初期形態の方が大域的最 適解近傍の解に至るまでの最適化のステップ数が増えるため, 必ずしも計算効率が良くなるとは言えない。 また, 有限要素解 析では, 連立方程式の解法に用いている前処理付き共役勾配法 の反復回数も計算効率に関係するため, 計算時間は要素数だけ ではなく, 最適化のパラメータの設定によっても変化する.

以上より, 本論文で提案したCA-IESO法は, パラメータの設定に より多様な大域的最適解近傍の解が求められる手法であり, また, どのような初期形態から出発しても, パラメータを適切に設定すれ ば, 多くの場合, 大域的最適解近傍の解に進化させることができる 手法であると結論づけられる.

なお, 有限要素解析では, 要素数の少ない初期解から出発しても, 計算効率が必ずしも良くならなかったが，今後，1ステップの計算 負荷がさらに大きくなる粒子法3)による解析でも同様の検討を行う 予定である.

\section{謝辞}

本解析のプリプロセッサには，（株）くいんとのVOXELCONを利 用している. (株) くいんとの石井惠三氏, 英山寛之氏の研究協力に 感謝の意を表する.

\section{参考文献}

1) Niiuchi, Y., Matsumoto S., Fujii, D.: Topology optimization of 3D structures using Improved ESO method, Journal of Structural and Construction Engineering (Transaction of AIJ), Vol.81, No.723, pp.851-858, 2016. 5 (in Japanese)

新内洋平, 松本慎也, 藤井大地：改良型 ESO 法を用いた 3 次元構造物の 位相最適化, 日本建築学会構造系論文集, Vol.81, No.723, pp.851-858, 2016. 5

2) Niiuchi, Y., Matsumoto, S., Fujii, D.: Computational morphogenesis of building structures using IESO method - Natural shape of buildings which resist vertical and seismic load, Journal of Structural and Construction Engineering (Transaction of AIJ), Vol.82, No.731, pp.97-103, 2017. 1 (in Japanese)
新内洋平, 松本慎也, 藤井大地：IESO 法を用いた建築構造の形態創生 鉛直荷重と地震荷重に抵抗する建物の自然形態, 日本建築学会構造系論 文集, Vol.82, No.731, pp.97-103, 2017. 1

3) Fujii, D., Yamashita, M., Manabe, M.: Topology optimization for elastic structures with finite deformation using HMPS method and IESO method, Journal of Structural and Construction Engineering (Transaction of AIJ), Vol.84, No.764, pp.1337-1344, 2019. 10 (in Japanese)

藤井大地，山下真輝，眞鍋匡利：HMPS 法と IESO 法を用いた有限変形 を伴う弾性構造体の位相最適化, 日本建築学会構造系論文集, Vol.84, No.764, pp.1337-1344, 2019.10

4) Bendsøe, M.P.: Optimal shape design as a material distribution problem, Structual Optimization, Vol.1, pp.193-202, 1989

5) Wang, M.Y., Wang, X and Guo, D.: A level Set Method for Structural Topology Optimization, Computer Methods in Applied Mechanics and Engineering, Vol. 192, No.1-2, pp.227-246, 2003

6) Huang, X., Xie, Y.M. : Convergent and mesh-independent solutions for the bi-directional evolutionary structural optimization method, Finite Elements in Analysis and Design, Vol.43, pp.1039-1049, 2007

7) Huang, X., Xie, Y.M.: Evolutionary Topology Optimization of Continuum Structures: Methods and Applications, Wily, 2010

8) Querin, O.M., Young, V., Steven, Y.M., Xie, Y.M.: Computational efficiency and validation of bi-directional evolutionary structural optimization, Computer methods in applied mechanics and enginieering, Vol.189, pp.559-573, 2000

9) Mitsui, K.: Autonomous generation and optimization of structural systems by cellular automaton, Journal of Structural and Construction Engineering (Transaction of AIJ), No.555, pp.101-105, 2002. 5 (in Japanese)

三井和男: セルオートマトンによる構造システムの自律的生成と最適化, 日本建築学会構造系論文集, No.555, pp.101-105, 2002.5

10) Fujii, D., Manabe, M.: Topology optimization of structures using CAESO Method, Journal of Structural and Construction Engineering (Transaction of AIJ), Vol.78, No.691, pp.1569-1574, 2013.9 (in Japanese)

藤井大地，真鍋匡利：CA-ESO 法による構造物の位相最適化，日本建築 学会構造系論文集, Vol.78, No.691, pp.1569-1574, 2013.9

11) Fujii, D., Okabe, R., Manabe, M.: Topology optimization of $3 \mathrm{D}$ structures using CA-ESO Method and voxel finite element method, Journal of Structural and Construction Engineering (Transaction of AIJ), Vol.79, No.703, pp.1279-1286, 2014.9 (in Japanese)

藤井大地, 岡部 諒, 真鍋匡利: CA-ESO 法とボクセル有限要素法を用 いた 3 次元構造物の位相最適化, 日本建築学会構造系論文集, Vol.79, No.703, pp.1279-1286, 2014.9

12) Ohmori, H. and Chui, C. Y.: Structural form creation by extended ESO method - Application to adaptive structures and shells -, Journal of Structural and Construction Engineering (Transaction of AIJ), No.552, pp.109-116, 2002.2 (in Japanese)

大森博司, 崔昌禹: 拡張 ESO 法による構造形態の創生一多目的適応型 構造とシェル構造への適用一, 日本建築学会構造系論文集, 第 552 号, pp.109-116, 2002.2

13) VOXELCON : https://www.quint.co.jp/jp/pro/vox/index.htm (accessed 2020.12.1) (参照 2020.12.1)

14) MicroAVs : https://www.cybernet.co.jp/avs/products/microavs/ (accessed 2020.12.1) (参照 2020.12.1)

15) Takada, T. and Matsuoka, T. : Application of linear programing method for truss topology optimization with objective functions of volume and compliance, Journal of Structural and Construction Engineering (Transaction of AIJ), No.598, pp.87-91, 2005.12 (in Japanese)

高田豊文, 松岡貴士：体積とコンプライアンスを目的関数としたトラ ス・トポロジー最適化問題への線形計画法の適用, 日本建築学会構造系 論文集，第 598 号, pp.87-91, 2005.12 


\title{
TOPOLOGY OPTIMIZATION OF STRUCTURES USING CA-IESO METHOD
}

\author{
Daiji FUJII $^{* 1}$, Masaki YAMASHITA ${ }^{* 2}$ and Makiko SHIMIZU ${ }^{* 3}$ \\ ${ }^{11}$ Prof., Faculty of Engineering, Kindai University, Dr.Eng. \\ ${ }^{2}$ Hojo Structure Research Institute, M.Eng. \\ ${ }^{3}$ Grad. Student, Graduate School of Systems Engineering, Kindai University
}

\begin{abstract}
The topology optimization method using voxel finite element method is an effectFive method to create various morphologies from rectangular parallelepiped design domain. Fujii et al. [1,2] created morphologies of building structures using such method. Also, Fujii and Yamashita et al. [3] have developed a method that can consider finite deformation by using the particle method (HMPS method) instead of the finite element method.
\end{abstract}

By the way, in the topology optimization using such a voxel analysis method, the individual element densities in the initial morphology are generally uniform. However, in 3D analysis, the number of elements (voxels) in the fixed design domain is hundreds of thousands, whereas the number of elements of the target solution is often about $10 \%$ of it. Therefore, if an optimal solution is obtained starting from an initial morphology with a small number of elements, the computational efficiency can be greatly improved especially in the analysis using the particle method. In addition, in the optimization problem, there is also a problem of making modifications while respecting the initial morphology set by the designer. For this reason, it is desirable that the topology optimization method obtain an optimal solution from any initial morphology. In this paper, we propose CAIESO, which is a combination of IESO (Improved ESO) method proposed in Refs.[1,2] and CA method, as a topology optimization method that can evolve from various initial morphologies.

In this paper, in order to verify the effectiveness of the proposed method, we first analyze the examples shown in Refs. [8,9]. Then, by comparing the solutions obtained from the three initial morphologies, we verify that they do not fall into local optimal solutions. In the two-dimensional problem, we also compare the solutions with the solutions obtained by CA-ESO method proposed in the past. Next, we analyze an example of creating a structure that supports a floor slab subjected to vertical loads and seismic loads.

The conclusions are as follows.

(1) From the initial morphology in which the initial density of all design target elements is 1, many optimal solutions near the global optimal solution can be obtained.

(2) When evolving from the initial morphology with small number of elements, the solutions near the global optimal solution can be obtained by setting the optimization parameters appropriately. However, depending on the initial morphology, no matter how the optimization parameters are adjusted, a local optimal solution may be obtained.

(3) By comparing the proposed method with CA-ESO method, the optimal solutions similar to the proposed method can be obtained by CA-ESO method. However, CA-ESO method does not provide as diverse solutions as the proposed method.

(4) In the case of morphological creation of the structure that supports the floor slab, the proposed method give an organic morphology like a tree. In addition, in the proposed method, the evolution process from the initial morphology is obserbed, so it seems to be effective in the problem of correcting the initial morphology.

(5) Since the proposed method can analyze with smaller number of elements, the calculation efficiency at each optimization step is good. However, in order to converge to a solution near the global optimal solution, it requires two to five times as many steps. Therefore, the calculation efficiency is not always good when obtaining a solution near the global optimal solution. 